\title{
Socio-economic Status of Vegetable Growers in Jammu Region of Jammu and Kashmir Union Territory
}

\section{Rigzin Disket", Anil Bhat ${ }^{1}$, Jyoti Kachroo², Manish K Sharma ${ }^{3}$, B.C. Sharma ${ }^{4}$, Bharat Bhushan ${ }^{5}$ and Malika Sharma ${ }^{1}$}

${ }^{*}$ Research Scholar, ${ }^{1}$ Assistant Professor(s), ${ }^{2}$ Professor $\mathcal{E}$ Head

Division of Agricultural Economics and ABM

${ }^{3}$ Professor $\mathcal{E}$ Head, Division of Statistics and Computer Science

${ }^{4}$ Professor $\mathcal{E}$ Head, Division of Agronomy, 5 Joint Registrar, Academics

Sher-e-Kashmir University of Agricultural Sciences and Technology of Jammu, Chatha-180009, JEK

Corresponding author: drbhatanil@gmail.com (ORCID ID: 0000-0002-4806-9467)

Received: 18-03-2021

Revised: 19-05-2021

Accepted: 15-06-2021

\begin{abstract}
The present study attempts to identify the socio-economic profile of vegetable farmers of Jammu district of Jammu and Kashmir UT. The study was conducted in ten blocks of Jammu district. Data for the study was collected from a sample of 240 vegetable growers. The findings of the study reveal that, the $21.25 \%$ of the vegetable farmers were illiterate and $78.75 \%$ were literate. Out of which maximum number of farmers have attend the education up to middle school 22.91 per cent. Among the sample about 65.83 per cent of farmers were marginal having less than 1 hectare land. As far as fixed resource structure is concerned, tractor constitute the highest overall average percentage 94.04 per cent with a value of ₹ 193542.00 while least percentage 0.31 per cent share was observed in knap sack sprayer with a value of ₹ 653.00. The study revealed that the livestock resource structure of the sampled vegetable firms shows the highest value in cow. The socio-economic status of the farmers can be improved by imparting technical knowledge/ training to vegetable farmers, increasing their education level and increasing their social participation.
\end{abstract}

\section{HIGHLIGHTS}

(0 The socio-economic status of the farmers can be improved by imparting technical knowledge/ training to vegetable farmers, increasing their education level and increasing their social participation.

(0 The fixed and livestock resource structure of the sampled vegetable firms shows the highest value in tractor and cow, respectively.

Keywords: Vegetables, socio-economic, farmers' income, education, resource structure

Vegetable growing is becoming increasingly important commercially among low-income households. It has a lot of potential for improving the socioeconomic situation of small and marginal farmers because vegetable farming produces a better yield and a higher economic return in a shorter period of time than food grain farming. Vegetable growing is a high-intensity programme that generates higher money per unit area and jobs in a short period of time. In India, where land

How to cite this article: Disket, R., Bhat, A., Kachroo, J., Sharma, M.K., Sharma, B.C., Bhushan, B. and Sharma, M. (2021). Socio-economic Status of Vegetable Growers in Jammu Region of Jammu and Kashmir Union Territory. Int. J. Soc. Sci., 10(02): 191-196.

Source of Support: None; Conflict of Interest: None (क) 
availability per capita has been steadily diminishing, small holdings are becoming smaller. Agriculture is becoming less profitable as the cost of agricultural inputs continues to grow. Whatever they are creating is insufficient to meet the family's daily needs for food and other necessities. Because small and marginal farmers do not have enough opportunity to give job possibilities for others, rural youngsters are travelling to urban areas in quest of work. Poor farmers, on the other hand, do not have sufficient sources of revenue to cover their daily needs. As a result, its become necessary to research the socioeconomic profile of vegetable growers in order to gain some insight into their lives. Training is critical for building confidence, motivation, and increasing an individual's efficiency. If we are going to train people, it will be more effective if we take into account the needs of the individuals (Singh et al. 2018). Union Territory of Jammu and Kashmir is having agriculture as the leading area in its economy where more than 70 percent of the population depends on it directly or indirectly. It also contributes about 60 per cent of revenue of Union Territory. Diversification of agriculture from traditional cereal based system to vegetables cultivation compatible with the comparative advantage of the region is the only viable solution to stabilize and raise farm income and increase employment opportunities (Joshi et al. 2004). The per capita availability is less than the prescribed requirement $200 \mathrm{gms}$ per person per day and to address the excess demand the vegetables are imported from outside J\&K. 1.99 lakh metric tons of vegetables have been imported ending November 2018. The area under vegetable crop in Jammu region during the year 201920 was 27,531 hectares with a production of about $706,307.86$ metric tons. Keeping in view above points, it is imperative to under the study with the objective to find out the socio-economic status of vegetable growers of Jammu district.

\section{MATERIALS AND METHODS}

The current study was conducted in the Jammu districts of Jammu \& Kashmir UT since the chosen district had the maximum area (3375 hectares) and production (73,585 metric tonnes) of vegetable crops. As a result, this districts is the actual representative of Jammu region of J\&K UT. A multi-stage random sampling design was used, with districts, villages, and vegetable producers as the first, second, and third stage units, respectively. Fifty percent blocks from Jammu district comprising of ten in number were selected on the basis of highest area under vegetable crops and two villages from each block were selected randomly to constitute twenty villages in total. A complete list of vegetable growers in the randomly selected villages was compiled along with their land holdings. A proportionate allocation approach is used to select 240 farmers at random from the sampled villages. The formula that was used to choose farmers from the sample villages is given below:

$$
n i=N i / N \times n
$$

Where,

$n i=$ Number of farmers to be sampled in $i^{\text {th }}$ villages; $\mathrm{Ni}=$ Total number of farmers in $i^{\text {th }}$ villages; $N=$ Total number of farmers in all the selected villages; $n=$ Total sampled size to be choosen.

Statistical tests like frequency counts and percentage analysis were used for analysis and interpretation of data.

\section{RESULTS AND DISCUSSION}

\section{Resource Structure and Social Status of sampled vegetable farms}

Individuals or social groups in society are primarily concerned with the social, economic, and political components of the socioeconomic approach. In general, the socioeconomic method focuses on determining an individual's or a community's adaptive potential based on internal variables such as age, education, land holding size, agricultural power, and so on. Variations in these elements are to blame for differences in farmer socioeconomic traits. The absolute value of input and output as well as relationship between them and among various constituents of input factor is determined by the farm resource structure. Therefore, the study of farm resource structure is essential for proper analysis of farm economy to know the economics of individual enterprises. The pattern and magnitude of investment 
in livestock resources and other fixed resources in farm enterprises are important indicators of income generating capacity of farmers. Livestock refers to one or more domesticated animals raised in an agricultural setting to produce commodities such as food, fiber and labour. The value of fixed and livestock resources was calculated using the present values.

\section{Family composition in sampled vegetable farms}

The family composition and family size are the important factors that affect the size of vegetable production and marketed surplus of vegetable in a household. Table 1 reveals information based on family composition in different sampled farms. The table includes data from survey conducted in ten different blocks viz. Arnia, Miran Sahib, R.S. Pura, Bishnah, Marh, Mandal Phallain, Khour, Pargwal, Suchetgarh, and Mathwar block of Jammu district. The Arnia block, consists of total family size of 4.82 persons per household, out of which 1.08 (37.96 per cent) were males, 1.91 (39.63 percent) were females and about 2.24 (22.41per cent) were children. The Bishnah block consist of total family size of 4.82 persons per household, out of which 1.83 (37.96 percent) were males, 2.41 (50 percent) were females and about 0.58 (12.03 percent) were children. The family size in Khour block consists of 4.91 persons, among which 1.79 (36.46 per cent) were males, 2.08 (42.36 percent) were females and 1.04 (21.18 percent) were children. In Pargwal block, the family size was 4.83 persons with 2 (41.38 percent) males, 2 (41.38 percent) females and 0.83 (17.24 percent) children. In R.S. Pura block, the family size was 4.87 persons with 1.96 (40.16 per cent) males, 2.21 (45.21 per cent) females and 0.71 (14.52 per cent) children. In Suchetgarh block, the family size was 5.08 persons with 2.04 (40.16 per cent) males, 2.5 (49.18 per cent) females and 0.54 (10.65 per cent) children. In Miran Sahab block, the family size was 5.37 persons with 2.71 (50.39 per cent) males, 1.75 (32.56 per cent) females and 0.92 (17.05 per cent) children. In Mathwar block, the family size was 5.25 persons with 2.12 (40.48 per cent) males, 2.46 (46.82 per cent) females and 0.66 (12.70 per cent) children. In Marh block, the family size was 5.37 persons with 2 (41.38 per cent) males, 2 (41.38 per cent) females and 0.83 (17.24 per cent) children. The overall average family size per household for both the districts was found to be 6.15 persons, with 2.27 (36.91 percent) males, 2.11 (29.77 percent) females and 1.76 (28.61 percent) children.

\section{Distribution of head of the households according to educational status}

The educational status of farm families is an indicator of human capital formation and economic status. An educated head of household is an important indicator

Table 1: Family composition in sampled vegetable farms (numbers)

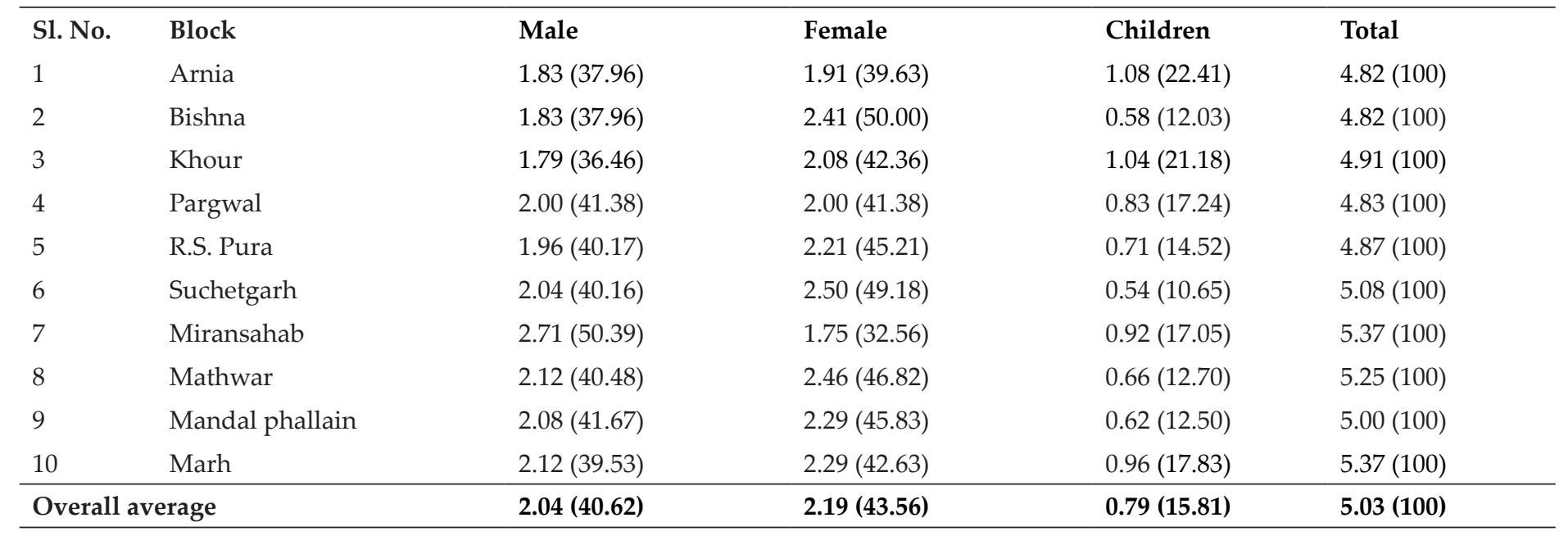

${ }^{*}$ Figures in parentheses are percentage of total. 
to influence decision making process in managing his livelihood sources efficiently and effectively. The distribution of sample households according to the education of the head of the family is shown in Table 2. Out of the total sampled farmers, 21.25 per cent were illiterate and 78.75 per cent were literate. The persons having primary level education were 21.67 per cent, middle level education were 22.91 per cent, sample whereas 21.67 per cent had education up to high school. Also there was 8.75 per cent respondents who had educational standard up to higher secondary while only 3.75 per cent respondents did graduation and above. Therefore it may be concluded that educational standard of majority of sampled farmers were concentrated up to middle school level. Adebayo and Oladele's (2013) findings were in line with the current findings.

Table 2: Distribution of head of household according to educational status

\begin{tabular}{lll}
\hline Education standard & No. of farmers & Percentage \\
\hline Illiterate & 51.00 & $(21.25)$ \\
Primary & 52.00 & $(21.67)$ \\
Middle & 55.00 & $(22.91)$ \\
High school & 52.00 & $(21.67)$ \\
Higher secondary & 21.00 & $(8.75)$ \\
Graduate and above & 9.00 & $(3.75)$ \\
\hline
\end{tabular}

\section{Sample respondents and holding size}

The sampled vegetable growers (240 farmers) were classified into three categories based on holding size (Table 3). Most of the farmers $(65.83 \%)$ belongs to marginal category with less than 1 hectare holding size whereas 30 per cent fall under small category with holding size in the range of 1-2 hectare, and only 4.17 farmer among the sample was falling under medium category (2-4 ha). The holding size in Jammu region in general and different blocks in particular is declining over the time due to fragmentation of land holdings, pressure from urbanization, division of land among the brothers of family etc. Agriculture has now become home of small and marginal farmers. Therefore, the future of sustainable agriculture growth and food security depends on the performance of small holders. The other reason may be the fragmentation of the holdings due to nuclear family system Mahajan (2016) has the same opinion.

Table 3: Classification of sample respondents as per holding size

\begin{tabular}{llll}
\hline S1. No. & Category & No. of farmers & Percentage \\
\hline 1 & Marginal (<1 ha) & 158.00 & 65.83 \\
2 & Small (1-2 ha) & 72.00 & 30.00 \\
3 & Medium (2-4 ha) & 10.00 & 4.17 \\
Total & & 240.00 & 100.00 \\
\hline
\end{tabular}

\section{Fixed resource structure of sampled farms}

Per household fixed resource structure of sampled vegetables farms of Jammu district is represented in Table 4. Among the fixed resource structure in the study area, tractor constitutes the highest overall average percentage (94.04 percent) with a value of ₹ 1, 93,542.00 while least percentage ( 0.31 percent) was of knapsack sprayers with a value of ₹ 653.40. Among the various blocks the Arnia block constitutes the highest percentage share of tractor (93.43 percent) with a value of ₹ 2,51,666.00 and least was found in pargwal block with a value of ₹ 56,250.00. As far as overall average of sampled vegetable farms is concerned, the tractor constitutes the highest percentage of 94.04 with value of ₹ $1,93,542.00$ and least percentage of 0.31 of knapsack sprayer with a value of ₹ 653.40. The table also represents the total value of fixed resources in the selected blocks of Jammu districts. Among all ten blocks, Marh has the highest total value (₹ 7,04,483.30), followed by Arnia block (₹ 2,71,273.14) and Mathwar block of Jammu district (₹ 2,34,000.00) with least value in Pargwal block (₹ 60,962.50) and overall average of ₹ 2,05,816 for all sampled vegetable farms. Findings are in the line with the results of Pawal (2014).

\section{Livestock resource structure of sampled farms}

Per unit Livestock resource structure of sampled vegetable farms is presented in Table 5 . The table reveals that total value of livestock structure was ₹ 35,708.40, ₹ $25,750.00$, ₹36,875.10, ₹25,750.00, ₹28,437.50, ₹22,229.16, ₹ 26,375.03, ₹ 30,604.19, ₹ 30,208.33 and ₹ 32,541.73 for Arnia, Miran Sahib, Khour, Bishnah, Marh, Mathwar, 
Table 4: Fixed resource structure of sampled vegetable growers (₹/ household)

\begin{tabular}{|c|c|c|c|c|c|c|c|c|c|c|c|}
\hline \multirow[b]{2}{*}{ Machinery } & \multicolumn{10}{|c|}{ Jammu district } & \multirow{2}{*}{$\begin{array}{l}\text { Overall } \\
\text { Average }\end{array}$} \\
\hline & Arnia & $\begin{array}{l}\text { Miran } \\
\text { Sahib }\end{array}$ & Khour & Bishna & Marh & Mathwar & Pargwal & Suchetgarh & R.S. Pura & $\begin{array}{l}\text { Mandal } \\
\text { phallain }\end{array}$ & \\
\hline Tractor & $\begin{array}{l}251666.60 \\
(92.78)\end{array}$ & $\begin{array}{l}135417.00 \\
(93.43)\end{array}$ & $\begin{array}{l}69166.60 \\
(91.80)\end{array}$ & $\begin{array}{l}139583.00 \\
(93.44)\end{array}$ & $\begin{array}{l}687500.00 \\
(9.80)\end{array}$ & $\begin{array}{l}212500.00 \\
(90.80)\end{array}$ & $\begin{array}{l}56250.00 \\
(92.30)\end{array}$ & $\begin{array}{l}75000.00 \\
(90.60)\end{array}$ & $\begin{array}{l}158333.00 \\
(91.09)\end{array}$ & $\begin{array}{l}150000.00 \\
(93.05)\end{array}$ & $\begin{array}{l}193542.00 \\
(94.04)\end{array}$ \\
\hline Motor & $\begin{array}{l}18500.00 \\
(6.82)\end{array}$ & $\begin{array}{l}8333.33 \\
(5.75)\end{array}$ & $\begin{array}{l}5625.00 \\
(7.50)\end{array}$ & $\begin{array}{l}8750.00 \\
(5.9)\end{array}$ & $\begin{array}{l}16500.00 \\
(0.23)\end{array}$ & $\begin{array}{l}20666.00 \\
(8.83)\end{array}$ & $\begin{array}{l}4583.33 \\
(7.52)\end{array}$ & $\begin{array}{l}7583.33 \\
(9.16)\end{array}$ & $\begin{array}{l}14833.30 \\
(8.53)\end{array}$ & $\begin{array}{l}10833.30 \\
(6.72)\end{array}$ & $\begin{array}{l}11620.80 \\
(5.65)\end{array}$ \\
\hline Total & $\begin{array}{l}271237.14 \\
(100)\end{array}$ & $\begin{array}{l}144946.00 \\
(100)\end{array}$ & $\begin{array}{l}75341.60 \\
\mathbf{( 1 0 0 )}\end{array}$ & $\begin{array}{l}149379.00 \\
(100)\end{array}$ & $\begin{array}{l}704483.22 \\
(100)\end{array}$ & $\begin{array}{l}234000.00 \\
(100)\end{array}$ & $\begin{array}{l}60962.50 \\
(100)\end{array}$ & $\begin{array}{l}82783.30 \\
(100)\end{array}$ & $\begin{array}{l}173817.00 \\
(100)\end{array}$ & $\begin{array}{l}161209.00 \\
(100)\end{array}$ & $\begin{array}{l}205816.00 \\
(100)\end{array}$ \\
\hline
\end{tabular}

*Figures in parentheses are percentage of total.

Table 5: Livestock resource structure of sampled vegetable growers (₹/ household)

\begin{tabular}{|c|c|c|c|c|c|c|c|c|c|c|c|}
\hline \multirow[b]{2}{*}{ Particulars } & \multicolumn{10}{|c|}{ Jammu district } & \multirow{2}{*}{$\begin{array}{l}\text { Overall } \\
\text { Average }\end{array}$} \\
\hline & Arnia & $\begin{array}{l}\text { Miran } \\
\text { sahib }\end{array}$ & Khour & Bishna & Marh & Mathwar & Pargwal & Suchetgarh & R.S. Pura & $\begin{array}{l}\text { Mandal } \\
\text { phallain }\end{array}$ & \\
\hline Cow & $\begin{array}{l}14916.70 \\
(41.80)\end{array}$ & $\begin{array}{l}8333.33 \\
(32.36)\end{array}$ & $\begin{array}{l}17666.70 \\
(47.91)\end{array}$ & $\begin{array}{l}8333.33 \\
(32.4)\end{array}$ & $\begin{array}{l}11125.00 \\
(39.12)\end{array}$ & $\begin{array}{l}7291.67 \\
(32.80)\end{array}$ & $\begin{array}{l}15583.33 \\
(59.08)\end{array}$ & $\begin{array}{l}11208.33 \\
(36.62)\end{array}$ & $\begin{array}{l}13250.00 \\
(43.86)\end{array}$ & $\begin{array}{l}13250.00 \\
(40.72)\end{array}$ & $\begin{array}{l}12095.84 \\
(41.08)\end{array}$ \\
\hline Calf & $\begin{array}{l}6833.33 \\
(19.14)\end{array}$ & $\begin{array}{l}6125.00 \\
(23.80)\end{array}$ & $\begin{array}{l}7375.00 \\
(20.00)\end{array}$ & $\begin{array}{l}6125-00 \\
(23.80)\end{array}$ & $\begin{array}{l}6125.00 \\
(21.53)\end{array}$ & $\begin{array}{l}5125.00 \\
(23.05)\end{array}$ & $\begin{array}{l}6500.00 \\
(24.64)\end{array}$ & $\begin{array}{l}5583.33 \\
(18.24)\end{array}$ & $\begin{array}{l}6750.00 \\
(22.34)\end{array}$ & $\begin{array}{l}6833.33 \\
(21.00)\end{array}$ & $\begin{array}{l}6337.50 \\
(21.52)\end{array}$ \\
\hline Heifer & $\begin{array}{l}4875.00 \\
(13.70)\end{array}$ & $\begin{array}{l}4166.67 \\
(16.18)\end{array}$ & $\begin{array}{l}3916.70 \\
(10.62)\end{array}$ & $\begin{array}{l}4166.70 \\
(16.20)\end{array}$ & $\begin{array}{l}3229.17 \\
(11.35)\end{array}$ & $\begin{array}{l}3854.16 \\
(17.33)\end{array}$ & $\begin{array}{l}3625.00 \\
(13.74)\end{array}$ & $\begin{array}{l}5395.83 \\
(17.63)\end{array}$ & $\begin{array}{l}3000.00 \\
(9.93)\end{array}$ & $\begin{array}{l}3916.70 \\
(12.03)\end{array}$ & $\begin{array}{l}4014.60 \\
(13.63)\end{array}$ \\
\hline Total & $\begin{array}{l}35708.40 \\
(100)\end{array}$ & $\begin{array}{l}25750.00 \\
(100)\end{array}$ & $\begin{array}{l}36875.10 \\
(100)\end{array}$ & $\begin{array}{l}25750.00 \\
(100)\end{array}$ & $\begin{array}{l}28437.50 \\
(100)\end{array}$ & $\begin{array}{l}22229.16 \\
(100)\end{array}$ & $\begin{array}{l}26375.03 \\
(100)\end{array}$ & $\begin{array}{l}30604.19 \\
(100)\end{array}$ & $\begin{array}{l}30208.33 \\
(100)\end{array}$ & $\begin{array}{l}32541.73 \\
(100)\end{array}$ & $\begin{array}{l}29447.94 \\
(100)\end{array}$ \\
\hline
\end{tabular}

Pargwal, Suchetgarh, R.S. Pura and Mandal Phallian, with an overall average of ₹ 29,447.94, respectively. The livestock structure included the value of cow, calf, buffalo and heifer. The value of cow for Arnia, Miransahab, Khour, Bishnah, Marh, Mathwar, Pargwal, Suchetgarh, R.S. Pura and Mandal Phallian was found to be ₹ 14,916.7, ₹ 8333.33, ₹ 17,666.70, ₹ 8333.33, ₹ 11,125.00, ₹ 7291.67, ₹ 15,583.33, ₹ 11,208.33, ₹ 13,250 and ₹ 13,250 and with an overall average of ₹ 12,095.84, respectively, The value of buffalo accounts for ₹ 9083.33 (25.44 per cent), ₹ 7125 (27.7 per cent), ₹ 7916.7 (21.5 per cent), ₹ 7125 (27.7 per cent) ₹ 7958.33 (27.98 per cent), ₹ 5958.33 (26.80 per cent), ₹ 666.7 (2.52 per cent), ₹ 8416.7 (27.50 per cent), ₹ 7208.33 (23.9 per cent) and ₹ 8541.7 (26.24 per cent) for Arnia, Miran Sahib, Khour, Bishnah, Marh,
Mathwar, Pargwal, Suchetgarh, R.S. Pura and Mandal Phallain, with an overall average of ₹ 7000.01 (23.8 percent), respectively. In case of heifer, the Suchetgarh block constitutes the highest value of ₹ 5395.83 (17.63 percent) followed by Arnia, Miransahib and Bishnah with a value of ₹ 4875.00, ₹ 4166.67 and ₹ 4166.70, respectively while the overall average was found to be ₹ 4014.06 (13.63 percent).

\section{CONCLUSION}

The overall average family size is 5.03 in the entire blocks; the average overall family size was highest in female 2.19 people per family followed by male 2.04 person per family and children 0.79 person per family. The natural resources in the surveyed villages primarily 
comprise land, water and livestock. The income of a household largely depends upon the utilization of available resources. These are the basic building blocks upon which households are able to undertake production, engage in labour markets and participate in reciprocal exchanges with other households. Farmers' socioeconomic traits are crucial for better policy choices. Based on the findings, it is suggested that vegetable farmers' socioeconomic position can be enhanced by providing technical knowledge/training, boosting their education level, and expanding their social participation.

\section{REFERENCES}

Adebayo, S.A. and Oladele, O.I. 2013. Socioeconomic status of organic vegetable farmers in South West Nigeria. Journal of Food, Agriculture E Environment, 11(2): 397-402.

Ellis, F. 2000. Rural Livelihoods and Diversity in Developing Countries, New York: Oxford University Press.
Mahajan, G. 2016. Effect of kodo millet (Paspalum scrobiculatum) based intercropping system on yield and economics of kodo millet under rainfed conditions, New Agriculturist, 27(1): 121124.

Pawal, R.D., Pisure, B.L. and Jamadar, C.R. 2014. Relationship between socio-economic characteristics of brinjal growers with their adoption gap in production practices. Trends in Biosciences, 7(19): 2903-2906.

Singh, J., Renstein, O., Thorpe, W. and Varma, A. 2007. Croplivestock interactions and livelihoods in the Indo-Gangetic Plains, Crop-livestock interactions scoping study Synthesis. CIMMYT-ILRI-RWC, New Delhi.

Singh, D., Prakash, S. and Saroj, P.L. 2006. Impact of perceived characteristic and adoption level of trained trainees in KVK about plant protection measures. Annuals Plant Protection Sciences, 14(1): 215-217. 